\title{
A influência da contextualização social, étnica e religiosa dos Gálatas para o entendimento e a vivência do princípio paulino de GI 6,15: "de resto, nem a circuncisão é alguma coisa, nem a incircuncisão, mas a nova criatura"
}

\author{
Orientador: Prof. Waldecir Gonzaga \\ Pesquisadora: Maria Conceição Messias \\ Fonte: Departamento de Teologia da PUC-Rio
}

\section{Introdução}

Segundo Leite (2014), a Carta aos Gálatas se apresenta como a mais importante entre os Escritos Paulinos [5], pois somente nela se encontra sua trajetória narrada por Paulo, além de destacar problemas das comunidades primitivas. Muitas comunidades cristãs hoje apresentam dificuldades e contradições, no que se refere à vivência do Evangelho pela falta de aprofundamento da fé e, a firmeza e autoridade de Paulo no anúncio do Evangelho, podem nos inspirar no enfrentamento com destes conflitos, bem auxiliar na reflexão e compreensão das dificuldades e contradições presentes nas primeiras comunidades cristãs e na Igreja atual, a exemplo dos vários tipos de intolerância que têm assolado a humanidade.

\section{Objetivos}

Identificar temas, à luz das Cartas Paulinas, que possam, potencialmente, auxiliar na reflexão e compreensão das dificuldades e contradições presentes nas primeiras comunidades cristãs e na Igreja atual, mas sobremaneira a partir da Carta aos Gálatas. Examinar a importância da contextualização social, étni- 
ca, geográfica e da evolução da religiosidade dos gálatas para o entendimento e do princípio paulino de Gl 6,15: "De resto, nem a circuncisão é alguma coisa, nem a incircuncisão, mas a nova criatura". Analisar as informações sobre a missão e a teologia de Paulo presentes neste princípio e os desafios exegéticos na comunidade dos Gálatas, que poderiam orientar a Igreja nos dias atuais, tendo em vista a sua aplicação pastoral. 